\title{
THE GLOBAL CRISIS OF 2008 AND INVESTIGATION OF THE REACTION OF OTHER MACROECONOMIC FACTORS TO A SHOCK ON THE UNEMPLOYMENT FACTOR OF THE COUNTRIES: AN APPLICATION ON DEVELOPED AND DEVELOPING COUNTRIES*
}

\section{Küresel Krizi ve Ülkelerin İşsizlik Faktörü Üzerindeki Şoka Diğer Makroekonomik Faktörlerin Tepkilerinin İncelenmesi: Gelişmiş ve Gelişmekte Olan Ülkeler Üzerine Uygulama}

Dr. Arş. Gör. Merve Arslan

ORCID: 0000-0001-5252-3741/Haliç Üniversitesi, İşletme Fakültesi.

Hamide Arslan

ORCID: 0000-0002-3256-4295/Ticaret Üniversitesi Doktora Öğrencisi.

Dr. Öğr. Üyesi Gülşah Gencer Çelik

ORCID: 0000-0001-8610-3673/Beykent Üniversitesi, İşletme Yönetimi Programı.

A R T I C L E I N F O
Article history:
Received: 18 October 2021
Accepted: 16 November 2021
Keywords: 2008 Crisis, Unemployment
Rates, Developed Countries,
Developing Countries, VAR Analysis.

Rates, Developed Countries,

Developing Countries, VAR Analysis.

\section{ABSTRACT}

All countries of the world were affected by the global mortgage crisis that took place in 2008. It is referred to as the new generation financial crisis type. Underdeveloped countries were more affected by the crises experienced in the past, whereas the 2008 crisis affected the developed economies more deeply. 31 countries were selected in this study. In the study, 18 developed countries and 13 developing countries were included. The changes in unemployment rates of countries in the post-crisis period are discussed. Then, it is aimed to investigate the reactions of other macroeconomic factors to a shock in the unemployment factor of countries with VAR analysis.

\section{Öz}

2008 yılında yaşanan küresel mortgage krizinden tüm dünya ülkeleri etkilenmiştir. 2008 krizi nesil finansal kriz türü olarak anılmaktadır. Daha önce gerçekleşmiş olan krizlerden az gelişmiş ve gelişmemiş ülkeler daha çok etkilenmiş iken yeni nesil finansal krizlerden olan 2008 Mortgage Krizi'nden gelişmiş ülkelerin daha çok etkilenmiş olabileceği tartışılmaktadır. Bu çalışmada OECD verilerine göre sınıflandırılmış gelişmiş ve gelişmekte olan 31 ülke seçilmiştir. Çalışmaya 18 gelişmiş ülke ve 13 gelişmekte olan ülke dâhil edilmiştir. Kriz sonrası dönemde ülkelerin işsizlik oranlarındaki değişimler araştırımıştır. Ardından, VAR analizi ile ülkelerin işsizlik faktöründe meydana gelen bir şoka diğer makroekonomik faktörlerin tepkilerinin ortaya konması hedeflenmiştir. 
The Global Crisis of 2008 and Investigation of The Reaction of Other

Macroeconomic Factors to a Shock on The Unemployment Factors of The

Countries: An Aplication on Developed and Developing Countries

İçtimaiyat Sosyal Bilimler Dergisi 2021, Cilt 5, Sayı 2

http://dergipark.gov.tr/ictimaiyat

\section{INTRODUCTION}

International Monetary Fund (IMF) financial crises are examined in four main groups as follows (IMF, 1998: 74).

* Currency Crisis (Currency Crisis): Currency (currency) crises can be expressed as speculative attacks on the exchange values of a currency against other foreign currencies. This type of attack; result in a serious depreciation or the sale of foreign currency reserves by the relevant authorities, or the upward revision of domestic interest rates, forcing the country's currency to defend itself. For an economy that is applying a fixed exchange rate regime, the (currency) currency crisis generally indicates the situation of the economy that is under pressure to abandon the widespread exchange rate regime. If speculative attacks are successful; currency will depreciate very seriously (Glick and Hutchison, 2011: 2).

* Systemic Financial Crisis: Systematic financial crises are defined as unsustainable shocks that occur in financial markets and prevent the effective functioning of the financial system, while negatively affecting the functioning of the real market (Marshall, 1998: 13). Systematic financial crises are usually caused by changes in the structure of political, economic and social life (Fernandez and Schumacher, 1997: 25).

* Banking Crisis: Banking crises mainly occur in the form of liquidity problems and bankruptcy as a result of the deterioration of bank balance sheets and the inability to finance short-term debt amounts with long-term receivables. This situation causes stagnation in financial and real markets, unusual fluctuations in interest rates and exchange rates, and inability to pay debts on time. In this respect, banking crises can be the trigger of systematic crises (Claessens et. al., 2001: 2).

* Foreign Debt Crisis: Since it is difficult to obtain financing especially for developing countries, foreign debt crises negatively affect the economic development and growth process by appearing in the form of restructuring of foreign debt or postponing debts in these countries. External debt crises are not just a concept related to developing countries. It is also expressed as a situation where a country that regularly pays its debts cannot pay the principal and interest of its obligations (Sachs, 1998: 244).

Twin crises are not examined as a single type of crisis in the finance literature, as they occur as a result of the interaction of the above 4 basic crisis types (Yücel and Kalyoncu, 2010: 55).

* Twin Crisis: Twin crises are defined by the simultaneous or interactive occurrence of banking and currency crises. The late 1980s and 1990s saw the collapse of the fixed exchange rate regime and financial systems. In this period of intense financial liberalization, twin crises in developing countries were caused by exchange rate and banking crises (Glick and Hutchison, 1999: 1). When the crises that occurred in Latin America and some Southeast Asian countries in the 1990s are examined, it is seen that these types of crises are included in the scope. The common features of the crises experienced in these countries are that they occur in developing countries and spread to neighboring countries by deepening one of the banking and currency crises due to financial liberalization (Marion, 1999: 19).

\section{Major Crises Experienced in the World}

- 1929 World Crisis-Economic Depression: The Great Depression of 1929 has been discussed many times in the history of economics and has been the subject of research articles. The process can be summarized as the collapse of the US stock market with a rapid decline from high value levels to zero within hours and dragging other financial markets downwards, causing a depression. The change in national income produced by various industries in the time period of 1929-1932, prepared by the US Department of Commerce to explain the Great Depression with numerical data, is presented in the figure below. According to the data, it is seen that the national income decreased by more than $50 \%$ in the time period of $1929-1932$. 
It is observed that the decrease in the construction sector occurred around $80 \%$, and the decrease in the manufacturing sector was around $70 \%$ in the relevant time period. It is seen that the only sector that has grown in this time period is the public sector (Karaş, 2016: 27).

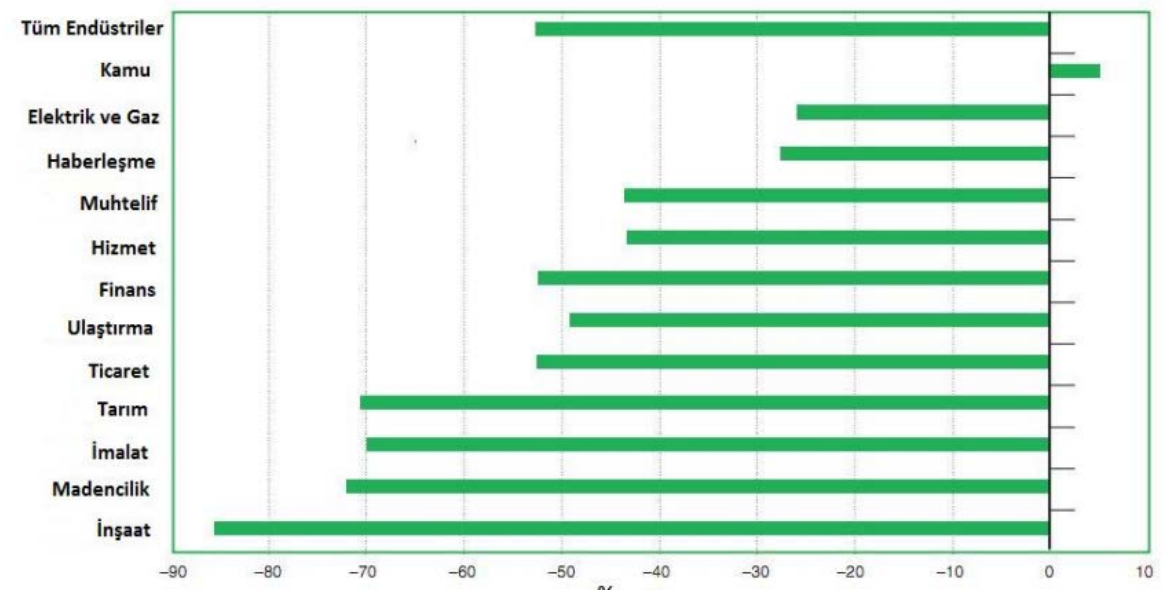

Figure 1. Graph of Change of National Income Produced in Industry in the USA for the Time Period of 1929-1932

Source: Marcuss ve Kane 2007: 33.

- (ERM) European Exchange Rate Mechanism Crisis (1992-1993): After the collapse of the Bretton Woods system, European countries aimed to prevent excessive fluctuations in exchange rates, regulate economic relations and strengthen the common market with the establishment of the European Monetary System and the European Exchange Rate Mechanism, which is an adjustable exchange rate system, in 1979. With the ERM, which was created to facilitate commercial and financial relations, the currencies of countries (ECU, Eurpean Currency Unit) were indexed to the European currency and left to fluctuate within the $-/+2.25 \%$ band gap. Member countries had to be more careful about the monetary and fiscal policy decisions they took in order to protect the determined fluctuation limits (Rivero and Bermejo, 2008: 1052).

- Latin American External Debt Crises (1982): The financial crises, which started to be seen in Latin America as of the 1980s, intensified in the 1990s and caused various countries to enter into a bottleneck at more frequent intervals. The underlying reason for the crisis to be experienced primarily in Latin American countries; It is an unstable macroeconomic and political structure with capital flows directed to these countries for the first time after financial liberalization (Krugman, 1994 \& Krugman 1999).

- Mexican Crisis (1994-1995): In December 1994, a financial crisis occurred in Mexico and the national currency, the peso, was devalued. With the conjuncture effect that increased in the late 1980s and early 1990s, significant volumes of short-term foreign funds entered Mexico for speculative investment purposes. As a result of the deficit in the current payments balance, which is increasing day by day, the tendency to save at low levels, the overvalued exchange rate and the increasing political instability, foreign capital has started to flee the country (Gür and Tosuner, 2002: 10-12).

- Argentina Crisis: Argentina, which was in a state of economic instability and hyperinflation in the 1980s, has implemented IMF-supported structural programs including trade liberalization, tax reform, privatization, establishment of a currency board and deregulation since 1989. With these measures implemented, inflation was reduced to single digits in a short time and a strong economic growth was achieved. However, the financial crisis that started in East Asian 
The Global Crisis of 2008 and Investigation of The Reaction of Other

Macroeconomic Factors to a Shock on The Unemployment Factors of The

Countries: An Aplication on Developed and Developing Countries İçimaiyat Sosyal Bilimler Dergisi 2021, Cilt 5, Sayı 2 http://dergipark.gov.tr/ictimaiyat

countries in 1997 and erupted in Russia and Brazil in 1998 and later caused Argentina to enter recession and unemployment to rise (Hornbeck, 2002: 1-2).

- Brazilian Crisis: Brazil, the largest economy in Latin America, is among the top 10 countries among the world's economies. Brazil II. It has a growth average of around 7.3\% from the World War II to the 1980s. Brazil's successful growth trend continued until the debt crisis in the 1980s, when Latin American countries faced the impact of financial liberalization. It was particularly affected by the Mexican crisis, and the growth rate data decreased to $1.8 \%$. The inflation rate also showed a significant increase, and the inflation rate, which was measured as $20 \%$ in 1972 , was measured as 5,000\% in 1993 (Filho and Lourdes, 2002: 109).

- Southeast Asian Crises (1997-1998): When the Southeast Asian crisis, which is a risk factor for the world financial system after the Latin American foreign debt crises in 1982, is evaluated in terms of its structural features and effects, it can be stated that it was the most important financial event of its period (Radelet and Sachs, 1998: 1). The Southeast Asian crisis differs from the crises in Latin America in the following ways; In the Southeast Asian crisis, interest rates did not increase and asset prices did not decrease. On the contrary, capital flows were channeled to movable and real estate investments and asset prices increased (Corsetti et al., 1998: 3). The financial crisis that broke out in Southeast Asian countries in 1997 first started in Thailand and spread to the Philippines, Malaysia, Indonesia, South Korea and many other countries.

- Russian Crisis (1998): After the collapse of the Soviet Union in 1990, the new leader of Russia, Boris Yeltsin, was elected in the first democratic elections of the Russian Federation. Together with Gaidar, who was Yeltsin's assistant, he started to obtain loans from abroad, mainly from the IMF, in order to cleanse Russia of its old plans and ensure its transition to a market economy, and removed all the existing restrictions between foreign trade and exchange rates. With the liberalization of foreign trade and the abolition of price controls, inflation started to accelerate upwards rapidly. As a solution to this problem, when money was printed by the Central Bank, inflation data exceeded $100 \%$ in 1991. In 1992, it climbed up to $2526 \%$ (Özel, 2005: 84).

\section{- 2008 Global Mortgage Crisis}

The 2008 global crisis that the world has faced has passed into the financial literature as the biggest crisis after the 1929 crisis. The 2008 crisis started in the financial markets in August 2007 and had devastating effects on the financial system and markets (IMF, 2008).

Countries have nationalized many banks and financial institutions in order to reduce the effects of the crisis and reduce the devastating effect. Especially developed countries have faced the biggest banking bankruptcies of the capitalist order. Especially in the economies of developed countries, it has been seen that the states have intervened in the financial system in an unprecedented way contrary to the essence of the functioning of the market economy (Feltonand Felton, 2009).

Adam Smith is known as the founder of the scientific foundations of capitalism. In his book The Wealth of Nations, published in 1776 by Adam Smith, it was stated that capitalism is profit-oriented and that profits are generally low in rich countries and high in poor countries. Parallel to this, it has been stated that the countries most affected by the crises are those with high profit levels (Önder, 2009). However, with the globalization process, the economies of the countries have been integrated. Therefore, the financial crises experienced after the 1990s had a great impact on both developing and developed countries (Caramazza et al., 2000).

The 2008 global crisis spread to all countries of the world in a short time and had negative effects on many macroeconomic variables such as unemployment rates, growth and inflation rates. The 2008 crisis did not remain only as an economic concept, but also caused the neoliberal 
The Global Crisis of 2008 and Investigation of The Reaction of Other

Macroeconomic Factors to a Shock on The Unemployment Factors of The

Countries: An Aplication on Developed and Developing Countries

İçimaiyat Sosyal Bilimler Dergisi 2021, Cilt 5, Sayı 2

conservative ideology to be questioned. Considering the 2008 crisis and its consequences, it was stated that the market economy is not a system that can solve all problems and the market economy has become questionable (Yeldan, 2008).

Mortgage bank etc. It can be expressed as the type of loan secured by the mortgage of the real estate as a result of the loan given to the individuals requesting loans in order to own a house by financial institutions (Fabozzi and Yuen, 1998: 11). In other words, mortgage represents the debt given to individuals or businesses for the purpose of purchasing a real property such as a house or land (Saunders and Cornett, 2001: 189).

\section{VAR Analysis}

18 developed countries and 13 developing countries were selected for the study. A VAR model has been established that includes all of the country's economies. With the VAR analysis, the level of unemployment rates of the country's economies during the 2008 crisis was investigated using quarterly data for the years 2008-2019. The table below provides information on the countries included in the study.

Table 1: Countries Included in the Study

\begin{tabular}{|l|l|}
\hline \multicolumn{1}{|c|}{ Developed countries } & \multicolumn{1}{c|}{ Developing countries } \\
\hline USA & Argentina \\
\hline Germany & Brazil \\
\hline Australia & Chile \\
\hline Belgium & Indonesia \\
\hline Denmark & South Africa \\
\hline Finland & South Korea \\
\hline France & India \\
\hline Holland & Iranian \\
\hline England & Malaysia \\
\hline Ireland & Mexican \\
\hline Spain & Russia \\
\hline Sweden & Turkey \\
\hline Switzerland & Chinese \\
\hline Italy & \\
\hline Japan & \\
\hline Canada & \\
\hline Norway & \\
\hline Greece & \\
\hline
\end{tabular}

Source: OECD Data

Table 2. Variables Included in the Study

\begin{tabular}{|l|l|l|l|l|}
\hline Variables & Abbreviation & Period & Frequency & Purpose of Use \\
\hline $\begin{array}{l}\text { GDP (\%) Growth } \\
\text { Rate }\end{array}$ & GDP & $\begin{array}{l}\text { 2008Q1- } \\
\text { 2019Q4 }\end{array}$ & Quarter Term & $\begin{array}{l}\text { The economic growth } \\
\text { rates of the countries are } \\
\text { included in the analysis as } \\
\text { a dependent variable. }\end{array}$ \\
\hline Unemployment & Unemployment & $\begin{array}{l}\text { 2008Q1- } \\
\text { 2019Q4 }\end{array}$ & Quarter Term & $\begin{array}{l}\text { It was included in the } \\
\text { analysis to observe how } \\
\text { the global crisis affected } \\
\text { the unemployment data of } \\
\text { the countries and to } \\
\text { observe the effects of } \\
\text { sudden changes in the }\end{array}$ \\
\hline
\end{tabular}


The Global Crisis of 2008 and Investigation of The Reaction of Other

Macroeconomic Factors to a Shock on The Unemployment Factors of The

Countries: An Aplication on Developed and Developing Countries

İçtimaiyat Sosyal Bilimler Dergisi 2021, Cilt 5, Sayı 2

\begin{tabular}{|c|c|c|c|c|}
\hline & & & & $\begin{array}{l}\text { unemployment rate on } \\
\text { the economy. }\end{array}$ \\
\hline Inflation & Inflation & $\begin{array}{l}\text { 2008Q1- } \\
2019 Q 4\end{array}$ & Quarter Term & $\begin{array}{l}\text { It has been included in the } \\
\text { analysis in order to } \\
\text { observe the effects of the } \\
\text { global crisis on the general } \\
\text { price level of the } \\
\text { countries. }\end{array}$ \\
\hline $\begin{array}{l}\text { Foreign Direct } \\
\text { Investment } \\
\text { (percent of GDP) }\end{array}$ & FDI/GDP & $\begin{array}{l}\text { 2008Q1- } \\
2019 Q 4\end{array}$ & Quarter Term & $\begin{array}{l}\text { It was included in the } \\
\text { analysis to investigate how } \\
\text { and to what extent the } \\
2008 \text { global crisis affected } \\
\text { the FDI levels of countries. }\end{array}$ \\
\hline $\begin{array}{l}\text { Current Account } \\
\text { Balance/GDP }\end{array}$ & $\begin{array}{l}\text { CurrentAccount } \\
\text { Balance }\end{array}$ & $\begin{array}{l}\text { 2008Q1- } \\
2019 Q 4\end{array}$ & Quarter Term & $\begin{array}{l}\text { It is aimed to investigate } \\
\text { the effects of the } 2008 \\
\text { global crisis on the current } \\
\text { account balance of } \\
\text { countries.. }\end{array}$ \\
\hline Variables & Abbreviation & Period & Frequency & Purpose of Use \\
\hline $\begin{array}{l}\text { GDP (\%) Growth } \\
\text { Rate }\end{array}$ & GDP & $\begin{array}{l}\text { 2008Q1- } \\
2019 Q 4\end{array}$ & Quarter Term & $\begin{array}{l}\text { The economic growth } \\
\text { rates of the countries are } \\
\text { included in the analysis as } \\
\text { a dependent variable. }\end{array}$ \\
\hline Unemployment & Unemployment & $\begin{array}{l}\text { 2008Q1- } \\
2019 Q 4\end{array}$ & Quarter Term & $\begin{array}{l}\text { It was included in the } \\
\text { analysis to observe how } \\
\text { the global crisis affected } \\
\text { the unemployment data of } \\
\text { the countries and to } \\
\text { observe the effects of } \\
\text { sudden changes in the } \\
\text { unemployment rate on } \\
\text { the economy. }\end{array}$ \\
\hline Inflation & Inflation & $\begin{array}{l}\text { 2008Q1- } \\
\text { 2019Q4 }\end{array}$ & Quarter Term & $\begin{array}{l}\text { It has been included in the } \\
\text { analysis in order to } \\
\text { observe the effects of the } \\
\text { global crisis on the general } \\
\text { price level of the } \\
\text { countries. }\end{array}$ \\
\hline $\begin{array}{l}\text { Foreign Direct } \\
\text { Investment } \\
\text { (percent of GDP) }\end{array}$ & FDI/GDP & $\begin{array}{l}\text { 2008Q1- } \\
2019 Q 4\end{array}$ & Quarter Term & $\begin{array}{l}\text { It was included in the } \\
\text { analysis to investigate how } \\
\text { and to what extent the } \\
2008 \text { global crisis affected } \\
\text { the FDI levels of countries. }\end{array}$ \\
\hline $\begin{array}{l}\text { Current Account } \\
\text { Balance/GDP }\end{array}$ & $\begin{array}{l}\text { CurrentAccount } \\
\text { Balance }\end{array}$ & $\begin{array}{l}\text { 2008Q1- } \\
2019 Q 4\end{array}$ & Quarter Term & $\begin{array}{l}\text { It is aimed to investigate } \\
\text { the effects of the } 2008 \\
\text { global crisis on the current } \\
\text { account balance of } \\
\text { countries.. }\end{array}$ \\
\hline
\end{tabular}

The 1st degree difference of all variables included in the study was taken. Because the time series must satisfy the stationarity condition. In order to achieve this, the ADF test was performed and the time series were made stationary. 
The Global Crisis of 2008 and Investigation of The Reaction of Other Macroeconomic Factors to a Shock on The Unemployment Factors of The Countries: An Aplication on Developed and Developing Countries İçimaiyat Sosyal Bilimler Dergisi 2021, Cilt 5, Sayı 2 http://dergipark.gov.tr/ictimaiyat

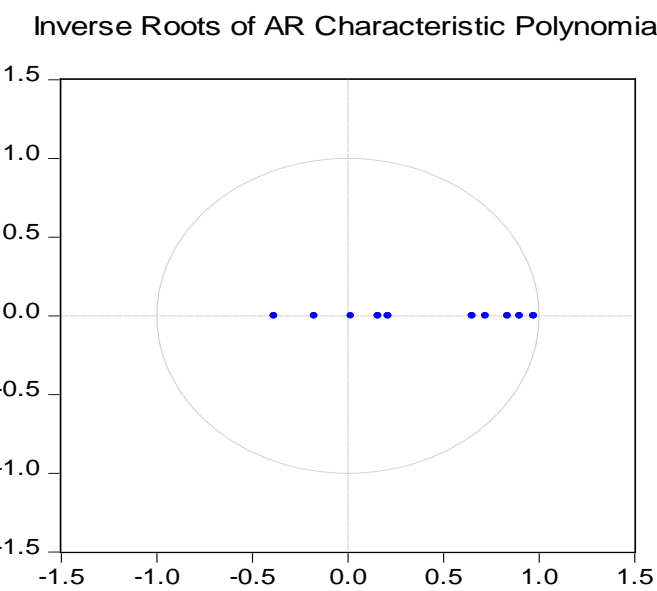

Figure 2 . The Position of the Inverse Roots of the AR Characteristic Polynomial on the Unit Circle

In the figure above, it is seen that the unit roots are located inside the circle. Therefore, it has been revealed that the VAR model is a structurally stable model.

\section{Effect-Response Analysis}

The DGP variable was included in the analysis as a dependent variable in the investigation of the countries' levels of being affected by the crisis. An impulse-response analysis was conducted to investigate the Response of Other Variables to Shock with a Standard Error Given to the GDP Variable.

Response to Cholesky One S.D. (d.f. adjusted) Innovations \pm 2 S.E.

Response of GDP to GDP

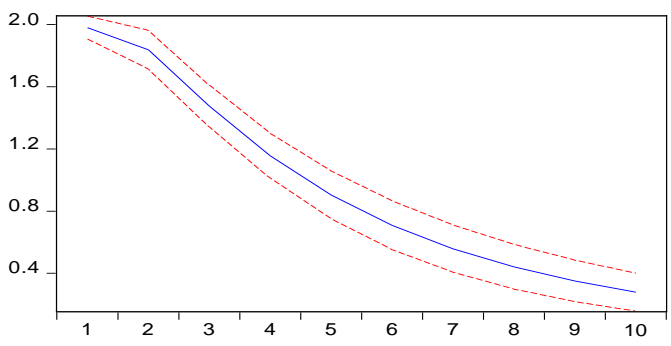

Response of ENFLASYON to GDP

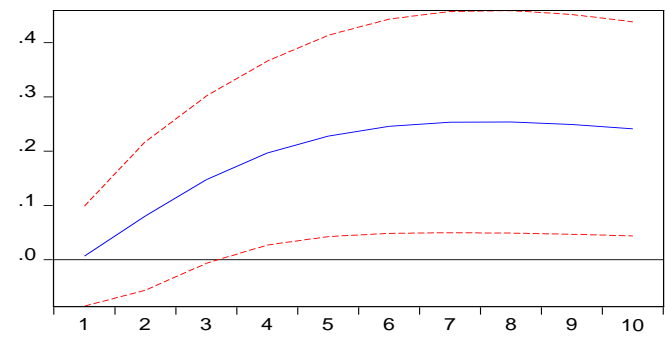

Response of CARIACIK to GDP

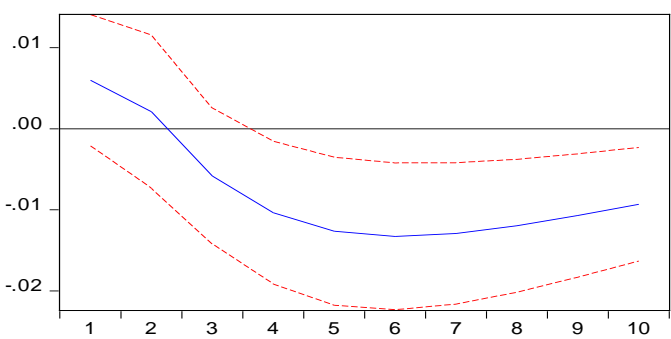

Response of ISSIZLIK to GDP

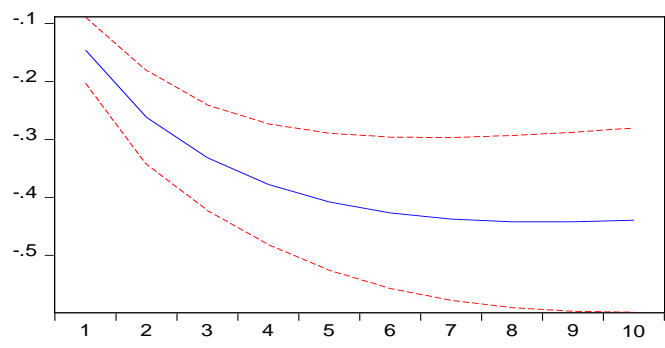

Response of DYYGDP to GDP

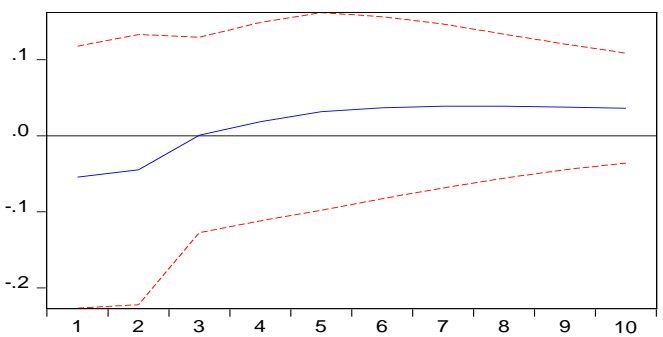


The Global Crisis of 2008 and Investigation of The Reaction of Other Macroeconomic Factors to a Shock on The Unemployment Factors of The Countries: An Aplication on Developed and Developing Countries İçimaiyat Sosyal Bilimler Dergisi 2021, Cilt 5, Sayı 2

Figure 3. A Standard Error Shock Given to the GDP Variable, Responses of Other Variables

The graphic values of the responses to the crisis are shown above. In the table below, the table value of the responses to the crisis is presented.

Table 3. Table Value of Responses to a Standard Error Shock, Other Variables Given to the GDP Variable

\begin{tabular}{|c|c|c|c|c|c|}
\hline Period & GDP & Unemployment & Inflation & FDI/ GDP & CurrentBalance/GDP \\
\hline \multirow[t]{2}{*}{1} & 1.979677 & -0.145995 & 0.006693 & -0.054399 & 0.005975 \\
\hline & (0.03695) & $(0.02846)$ & $(0.04605)$ & $(0.08613)$ & $(0.00404)$ \\
\hline \multirow[t]{2}{*}{2} & 1.837771 & -0.262034 & 0.080607 & -0.044707 & 0.002103 \\
\hline & $(0.06238)$ & $(0.04047)$ & $(0.06837)$ & $(0.08884)$ & $(0.00473)$ \\
\hline \multirow[t]{2}{*}{3} & 1.475701 & -0.331748 & 0.147516 & 0.000931 & -0.005837 \\
\hline & $(0.06695)$ & $(0.04560)$ & (0.07709) & $(0.06422)$ & (0.00419) \\
\hline \multirow[t]{2}{*}{4} & 1.155405 & -0.377705 & 0.196543 & 0.018396 & -0.010361 \\
\hline & $(0.07204)$ & $(0.05212)$ & $(0.08473)$ & $(0.06524)$ & $(0.00440)$ \\
\hline \multirow[t]{2}{*}{5} & 0.903448 & -0.407861 & 0.227953 & 0.031799 & -0.012640 \\
\hline & $(0.07687)$ & $(0.05910)$ & (0.09277) & (0.06495) & $(0.00456)$ \\
\hline \multirow[t]{2}{*}{6} & 0.708654 & -0.426715 & 0.245694 & 0.036738 & -0.013285 \\
\hline & $(0.07818)$ & $(0.06526)$ & (0.09869) & $(0.05982)$ & $(0.00453)$ \\
\hline \multirow[t]{2}{*}{7} & 0.558115 & -0.437348 & 0.253343 & 0.038941 & -0.012925 \\
\hline & $(0.07614)$ & $(0.07028)$ & (0.10177) & $(0.05393)$ & $(0.00436)$ \\
\hline \multirow[t]{2}{*}{8} & 0.441269 & -0.441975 & 0.253771 & 0.038807 & -0.011972 \\
\hline & $(0.07196)$ & $(0.07420)$ & $(0.10240)$ & $(0.04732)$ & $(0.00410)$ \\
\hline \multirow[t]{2}{*}{9} & 0.350126 & -0.442229 & 0.249133 & 0.037774 & -0.010709 \\
\hline & $(0.06668)$ & (0.07718) & (0.10117) & $(0.04134)$ & $(0.00380)$ \\
\hline \multirow[t]{2}{*}{10} & 0.278666 & -0.439311 & 0.241035 & 0.036230 & -0.009319 \\
\hline & $(0.06107)$ & $(0.07937)$ & $(0.09864)$ & $(0.03611)$ & $(0.00350)$ \\
\hline
\end{tabular}

According to the results of the Impulse-Response analysis, the unemployment series reacted negatively to a standard error shock originating from GDP in every period, and it is seen that the severity of the reaction is gradually increasing. Unemployment rate of countries is -0.145995 (-) in the 1st period, -0.262034 in the 2 nd period, -0.331748 in the 3 rd period, -0.377705 in the 4 th period, - 
0.407861 in the 5 th period, and -0.407861 in the 6th period, to a standard error shock originating from GDP. $0.426715,-0.437348$ in the 7th period, -0.441975 in the 8 th period, -0.442229 in the 9 th period and -0.439311 in the 10th period. The reaction of the unemployment rates of the countries to the 2008 crisis did not disappear for 10 periods, and it is observed that the severity of the reaction increased in the $(-)$ direction over time.

According to the graphical and table values of the Impulse-Response analysis, it is seen that the inflation series responds to a GDP-induced standard error shock in the (+) direction in every period and in the same direction with increasing intensity over time. Inflation rates of countries gave the weakest response to the shock from GDP in the first period, and this reaction was measured as 0.006693. Inflation rates are 0.080607 in the 2 nd period, 0.147516 in the 3rd period, 0.196543 in the 4th period, 0.227953 in the 5th period, 0.245694 in the 6th period, 0.253343 in the 7th period, 0.253771 in the 8 th period, 0.249133 in the 9 th period and 0.241035 in the 10 th period.

It is aimed to investigate the direction and severity of the response of the countries' FDI/GDP variable to the 2008 crisis by periods. It is seen that the reaction of the foreign direct investment level of the countries to the crisis was (-) in the first 2 periods, while the reaction in the third period was very close to zero, and the direction of the reaction was (+) in the following periods. FDI/ GDP variable to a shock from GDP variable 1st period -0.054399 , 2nd period -0.044707 , 3rd period 0.000931 , 4th period 0.018396 , 5 th period 0.031799 , 6 th period 0.036738 , 7 th period 0.038941 , 8 th period 0.038807 , 9th period 0.037774 and 10 th period 0.036230 intensity reaction developed.

It is aimed to investigate the direction and severity of the response of the countries' current account deficit data to the 2008 crisis with impact-reaction analysis. It is seen that the current account deficit data of 31 countries reacted to the 2008 crisis in the (+) direction in the first two periods, and the direction of the reaction was (-) as of the third period. It is seen that the severity of the (-) directional reaction, which started in the 3rd period, increased in the same direction until the 6th period, and the strongest reaction occurred in the 6th period, and the (-) directional reaction continued to decrease in the following periods. The response of the current account balance series to the crisis 1st period 0.005975 , 2nd period 0.002103 , 3rd period -0.005837 , 4th period -0.010361 , 5 th period 0.012640 , 6th period -0.013285 , 7 th period -0.012925 , 8 th period -0.011972 , 9 th period -0.010709 and 10th period -0.009319 . 
The Global Crisis of 2008 and Investigation of The Reaction of Other Macroeconomic Factors to a Shock on The Unemployment Factors of The Countries: An Aplication on Developed and Developing Countries İçimaiyat Sosyal Bilimler Dergisi 2021, Cilt 5, Sayı 2

Response to Cholesky One S.D. (d.f. adjusted) Innovations \pm 2 S.E.

Response of GDP to ISSIZLIK

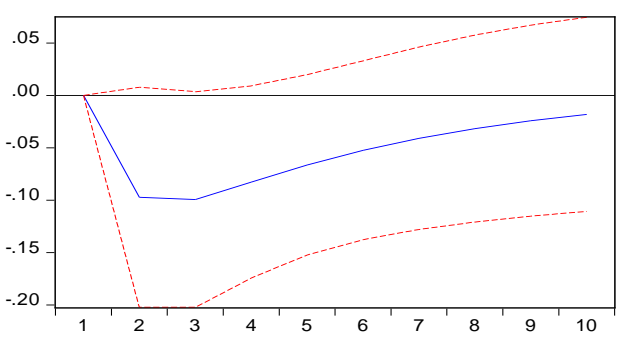

Response of ENFLASYON to ISSIZLIK

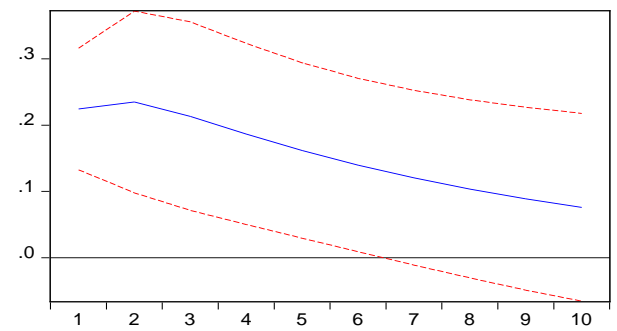

Response of CARIA_IK_GDP to ISSIZLIK

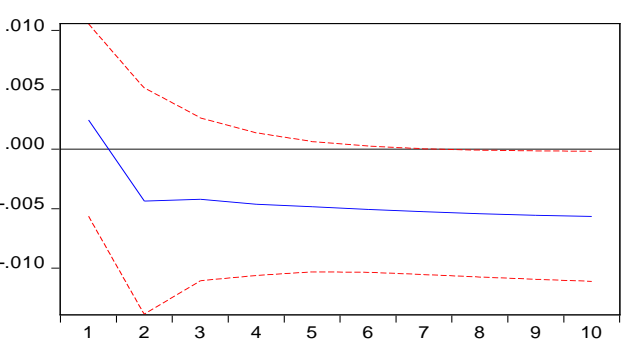

Response of ISSIZLIK to ISSIZLIK

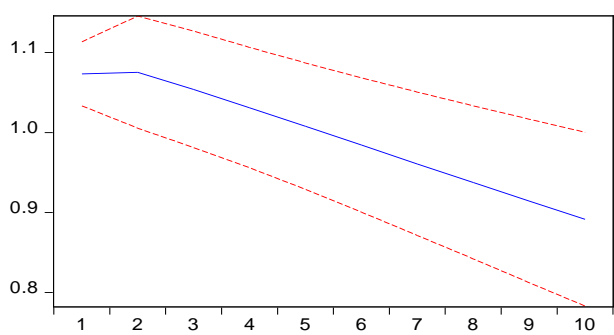

Response of DYYGDP to ISSIZLIK

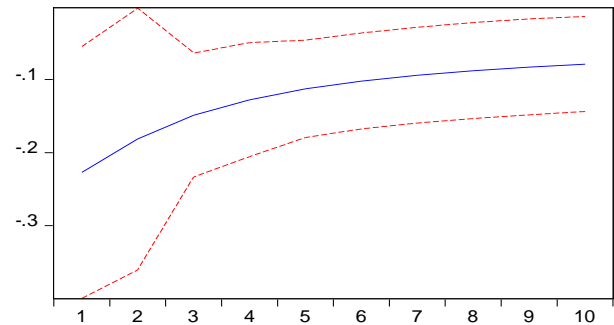

Figure 4. One Standard Error Shock Given to the Unemployment Variable, Reactions of Other Variables

Table 4. Table Value of Responses to a Standard Error Shock, Other Variables Given to the Unemployment

\begin{tabular}{cccccc}
\hline Period & GDP & Unemployment & Inflation & FDI/GDP & CurrentBalance/GDP \\
\hline 1 & 0.000000 & 1.073190 & 0.224239 & -0.227092 & 0.002449 \\
& $(0.00000)$ & $(0.02003)$ & $(0.04586)$ & $(0.08602)$ & $(0.00404)$ \\
2 & -0.097166 & 1.075328 & 0.234908 & -0.181347 & -0.004364 \\
3 & $(0.05254)$ & $(0.03502)$ & $(0.06849)$ & $(0.08952)$ & $(0.00476)$ \\
& -0.099325 & 1.053811 & 0.213273 & -0.148807 & -0.004212 \\
& $(0.05146)$ & $(0.03640)$ & $(0.07105)$ & $(0.04239)$ & $(0.00342)$ \\
& -0.082715 & 1.031022 & 0.186484 & -0.127701 & -0.004622 \\
& $(0.04586)$ & $(0.03764)$ & $(0.06824)$ & $(0.03901)$ & $(0.00299)$
\end{tabular}


The Global Crisis of 2008 and Investigation of The Reaction of Other

Macroeconomic Factors to a Shock on The Unemployment Factors of The

Countries: An Aplication on Developed and Developing Countries İçtimaiyat Sosyal Bilimler Dergisi 2021, Cilt 5, Sayı 2 http://dergipark.gov.tr/ictimaiyat

\begin{tabular}{|c|c|c|c|c|c|}
\hline 5 & -0.066265 & 1.007708 & 0.161668 & -0.112837 & -0.004836 \\
\hline & $(0.04308)$ & $(0.03954)$ & $(0.06607)$ & $(0.03324)$ & $(0.00274)$ \\
\hline 6 & -0.052312 & 0.984232 & 0.139695 & -0.102104 & -0.005058 \\
\hline & (0.04272) & (0.04196) & $(0.06537)$ & $(0.03280)$ & $(0.00265)$ \\
\hline 7 & -0.040904 & 0.960759 & 0.120459 & -0.094084 & -0.005252 \\
\hline & (0.04349) & (0.04478) & $(0.06587)$ & $(0.03274)$ & $(0.00264)$ \\
\hline 8 & -0.031630 & 0.937416 & 0.103644 & -0.087900 & -0.005417 \\
\hline & $(0.04458)$ & (0.04785) & (0.06716) & $(0.03282)$ & (0.00267) \\
\hline 9 & -0.024094 & 0.914296 & 0.088937 & -0.082967 & -0.005548 \\
\hline & (0.04559) & (0.05107) & (0.06887) & (0.03277) & $(0.00270)$ \\
\hline 10 & -0.017965 & 0.891468 & 0.076061 & -0.078900 & -0.005646 \\
\hline & $(0.04636)$ & (0.05438) & (0.07073) & $(0.03254)$ & $(0.00273)$ \\
\hline
\end{tabular}

According to the results of the Impact-Response Analysis, quarterly growth rates of 31 countries (GDP) did not react to a standard error shock caused by the unemployment rate in the first period, but reacted in the (-) direction in all periods starting from the second period. It is observed that the strongest reaction occurred in the $2 \mathrm{nd}$, 3rd and 4th periods, and the severity of the reaction continued to decrease in the following periods. The weakest reaction occurred in the last period. The GDP variable of the countries to the shock on the unemployment rate is -0.097166 in the 2 nd period, -0.099325 in the 3 rd period, -0.082715 in the 4 th period, -0.066265 in the 5 th period, -0.052312 in the 6th period, -0.040904 in the 7 th period, -0.031630 in the 8 th period, In the 9th period, it reacted with a severity of -0.024094 , and in the 10 th period -0.017965 .

According to the results of the Impulse-Response analysis, the inflation rate of 31 countries reacted in a (+) direction to a standard error shock originating from the unemployment rate in all periods. The strongest reaction occurred in the first three periods, and the severity of the reaction continued in a decreasing trend in the following periods. The response of the inflation rate to a standard error shock originating from the unemployment rate is 0.224239 in the 1 st period, 0.234908 in the 2 nd period, 0.21327 in the 3 rd period, 0.186484 in the 4 th period, 0.161668 in the 5 th period, 0.139695 in the 6th period, 0.120459 in the 7th period, 0.103644 in the 8th period, 9th period is measured as 0.088937 and 10th period as 0.076061 .

When the Impact-Response analyzes are examined, it is seen that the foreign direct investment levels (dp/gdp) of 31 countries reacted in the (-) direction to the unemployment-induced shock in all periods. It is seen that the strongest reaction occurs in the first period, and the severity of the reaction continues to decrease in the following periods. The reaction of the foreign direct investment levels of the countries 1 st period -0.227092 , 2nd period -0.181347 , 3rd period -0.148807 , 4 th period -0.127701 , 5th period $-0.112837,6$ th period -0.102104 , 7 th period -0.094084 , 8 The first period was -0.087900 , the 9 th period was -0.087900 and the 10 th period was -0.078900 .

Considering the Impact-Response tables and graphs, the current account balance (current account deficit/gdp) of 31 countries reacted to the unemployment-induced shock in the direction of 
The Global Crisis of 2008 and Investigation of The Reaction of Other

Macroeconomic Factors to a Shock on The Unemployment Factors of The

Countries: An Aplication on Developed and Developing Countries İçimaiyat Sosyal Bilimler Dergisi 2021, Cilt 5, Sayı 2 http://dergipark.gov.tr/ictimaiyat

$0.002449(+)$ in the first period. It is seen that the severity of the reaction continues in an increasing trend over time. The response of the current account balance variable is 0.002449 in the 1 st period, 0.004364 in the 2 nd period, -0.004212 in the 3rd period, -0.004622 in the 4th period, -0.004836 in the 5th period, -0.005058 in the 6th period, -0.005252 in the 7 th period, It is measured as -0.005417 , 9th period as -0.005548 and 10 th period as -0.005646 .

\section{CONCLUSION}

The 2008 Mortgage Crisis, which has been experienced, has passed into the finance literature as the most destructive crisis that has occurred after the 1929 crisis. The macroeconomic indicators of the country's economies were affected by this crisis and the effects of the crisis continued for a while.

In this study, quarterly data of 31 countries for the years 2008-2019 were included in the analysis. A VAR model has been established with 18 developed countries and 13 developing countries. It has been proven that the established model is structurally stable as all the roots are in the unit circle. With the ADF test, all time series are made stationary by taking the 1st degree difference of all time series. Then, impact-response analyzes were carried out, and both graphic and tabular values of the responses to the crisis were presented and interpreted in detail.

Research data were collected until 2019. Because the effect of the Covid-19 Pandemic process, which still continues in 2020 and 2021, on the economy and macroeconomic factors is thought to be stronger than the 2008 crisis. It is planned to address the effects of the Covid-19 pandemic on world economies in the future.

Countries need to carry out investment and production activities with high added value in order to fight crises and economic depressions in the strongest way possible. For structural economic recovery and permanent economic stability, it is recommended to transfer production and investment activities with the most accurate and high added value projects.

\section{REFERENCES}

Caramazza, F., Rancesco, L. R. and Salgado, R. (2000). Trade and Financial Contagion in currency Crises, IMF Working Paper, WP/00, http://www.imf.org.

Claessens, S., Klıngebıel, D., Laeven, J. (2001). Financial Restructuring in Banking and Corporate Sector Crises: What Policies to Pursue?, NBER Working Paper, No. 8386.

Corsetti, G., Pesenti, P., and Roubini, N., (1998). What Caused the Asian Currency and Financial Crisis? Part I: A Macroeconomic Overview, National Bureau of Economic Research

Fabozzı, F., Yuen, D. (1998). Managing MBS Portfolios, F.J. Fabozzi Associates, Pennsylvania.

Glick R. and M. M. Hutchison, 2011. Currency crises, Working Paper Series 2011-22, Federal Reserve Bank of San Francisco.

Gür, T.H. and Tosuner, A., 2002. Para ve Finansal Krizlerin Öncü Göstergeleri, Hacettepe Üniversitesi İktisadi ve İdari Bilimler Fakültesi Dergisi, 20/1, 9-36.

Hornbeck, J.F., (2002). The Argentine Financial Crisis: A Chronology of Events, CRS Report for Congress, RS21130. January 31.

IMF (1998). Financial Crises: Characteristics and Indicators of Vulnerability in Financial Crises: Causes And Indicators, World Economic And Finacial Surveys World Economic Outlook

IMF (2008). World Economic Outlook, April, http://www.imf.org.

Krugman, P. (1994). The Myth of Asia's Miracle, Foreign Affairs, pp. 62-78.

Krugman, P. (1999). Balance Sheets, The Transfer Problem and Financial Crises, International Finance and Financial Crises, pp 31-55. 
The Global Crisis of 2008 and Investigation of The Reaction of Other Macroeconomic Factors to a Shock on The Unemployment Factors of The

Countries: An Aplication on Developed and Developing Countries İçtimaiyat Sosyal Bilimler Dergisi 2021, Cilt 5, Sayı 2 http://dergipark.gov.tr/ictimaiyat

Marcuss, R. D. and Kane R. E., (2007). U.S. National Income and Product Statistics, Born of the Great Depression and World War II, Survey of Current Business, February 2007. 87(2): 32-46.

Marion, N. P., (1999). Some Parallels Between Currency and Banking Crises, International Finance and Financial Crises pp 1-29.

Marshall, D 1998. Understanding The Asian crisis: Systemic Risk as Coordination Failure, Economic PerspectivesFederal Reserve Bank of Chicago, No.22, 13-28.

Reinhart, C. M. and Felton, A. (2009). The First Global Financial Crisis of the 21st Century, Part II: Introduction, MPRA Paper No. 13607, http://www.mpra.ub.uni-muenchen.de.

Önder, ì. (2009). Küresel Kriz ve Türkiye Ekonomisi, Muhasebe ve Finansman Dergisi, 42, 12- 25.

Özel, S., (2005). Global Finansal Krizler, Deniz Kültür, İstanbul.

Radelet, S. and Sachs, J.D., (1998). The Onset of the East Asian Financial Crisis, NBER Working Paper, No. 6680

Saad-Filho, A. and Lourdes, R.M., (2002). Inflation and Stabilization in Brazil: A Political Economy Analysis, Review of Radical Political Economies, 34/2, 109-135.

Sachs, J.D., (1998). Alternative Approaches to Financial Crises in Emerging Markets, Capital Flows and Financial Crises, New York, Cornell Univercity Press.

Saunders, A., Cornett, M.M. (2001). Financial Markets and Institutions, McGraw-Hill Higher Education, New York.

Sosvilla-Rıvero, S. and Perez-Bermejo, F., (2008). Political and Institutional Factors in Regime Changes in the ERM: An Application of Duration Analysis, The World Economy, 31/8, 1049-1077.

Yeldan, E. (2008). Avrupa'da Bir Hayalet Dolaşıyor, Ekonomi Politik, http://www.bilkent.edu.tr. www.cnnturk.com/2012/ekonomi/dunya/12/06/rumlar.iflas.bayragini.cekti/687544.0/index.html. 